Sylwestrzak, D. (2020). Aktywizacja osób starszych na poziomie gminy. W: I. Lipowicz, M. Małecka-Łyszczek (red.). Ekonomia Społeczna. Wykluczenie społeczne (s. 58-67). Kraków: Uniwersytet Ekonomiczny w Krakowie. https://doi.org/10.15678/ES.2020.1.06

\title{
Aktywizacja osób starszych na poziomie gminy
}

\section{Dorota Sylwestrzak}

\begin{abstract}
Streszczenie: Wieloletni program „Seniort” na lata 2015-2020 przyjęty Uchwałą nr 34 przez Radę Ministrów w dniu 17 marca 2015 r. to kolejny dokument rządowy o charakterze planistycznym, który dotyczy problematyki aktywizacji osób starszych. Przedmiotem opracowania jest przede wszystkim analiza obowiązującego stanu prawnego, stanowiska judykatury oraz doktryny na temat realizacji zadań. Rozważania prowadzone są z punktu widzenia form i sposobów realizacji przez gminę zadań w zakresie aktywizacji osób starszych w ramach programu "Senior+" oraz oceny charakteru tych zadań. W artykule zastosowano przede wszystkim metodę teoretyczno-dogmatyczną.
\end{abstract}

Słowa kluczowe: aktywizacja osób starszych, senior+, zadania gminy

Kody JEL: J14; J18

\section{Wprowadzenie}

W Polsce - podobnie jak i w innych krajach EU - dostrzegamy proces starzenia się społeczeństwa. Problematyka aktywizacji osób starszych stanowi przedmiot zainteresowania różnych dyscyplin naukowych. Zjawiskiem tym zajmują się nauki ekonomiczne, socjologiczne, filozoficzne, ale także prawne oraz ekonomia społeczna (u.p.s., 2004, art. 21a zwana dalej jako u.p.s.). Z punktu widzenia prawa należy zauważyć, że problematyka aktywizacji osób starszych w różnych sektorach - na rynku usług finansowych, teleinformatycznych i e-usług (Minkowski, 2013, s. 147-157), pracy, zdrowia, edukacji, kultury, infrastruktury, polityki mieszkaniowej, bezpieczeństwa; oraz przeciwdziałania ich wykluczeniu, realizowana jest na poziomie prawa międzynarodowego (Mikołajczyk, 2012; Behr, 2018, s. 119-131; Piechowiak, 2009, s. 130-137), unijnego (Malarewicz-Jakubów, 2017; Mikołajczyk, 2012) oraz krajowego (Blicharz, 2018, s. 35-77). Problematyka stanowi przedmiot zainteresowania doktryny prawa konstytucyjnego (Piechowiak, 2009, s. 140-145. W nauce zwraca się uwagę na niedostatek regulacji na gruncie Konstytucji RP w zakresie wykluczenia społecznego (Tuleja, 2009, s. 160).

Należy zauważyć, że aktywizacja osób starszych stanowi przedmiot materii ustawowej, ale także aktów o charakterze wykonawczym (planistycznych, programów). Uchwalane są długofalowe programy w różnych dziedzinach, w szczególności w zakresie profilaktyki zdrowotnej, czy też rozbudowanej pomocy społecznej. Rozwiązania prawne obejmują przepisy ustrojowe, materialne i proceduralne. Działania podejmowane są zarówno na szczeblu centralnym, jak i lokalnym (samorządowym). Na poziomie gminy jednym z takich sposobów aktywizacji osób starszych jest chociażby inicjatywa tworzenia gminnych rad seniorów - organów o charakterze konsultacyjnym, doradczym (Chmielnicki, 2013; Moll, 2015, s. 66-76; Mędrzycki, 2017, s. 119-131; 
Andruszkiewicz, 2017, s. 21-31; Augustyniak i in., 2016). Mając na uwadze prowadzone rozważania, na uwagę w szczególności zasługują te działania państwa, które ukierunkowane są na zwiększenie aktywnego uczestniczenia w życiu społecznym osób starszych.

Zasadniczym celem opracowania będzie analiza rozwiązań instytucjonalnych oraz ocena ich charakteru prawnego. Przedmiotem rozważań będą zadania gminy podejmowane na rzecz aktywizacji osób starszych w zakresie wieloletniego programu "Senior+" na lata 2015-2020. Prowadzone rozważania mają prowadzić do oceny tego: w jaki sposób oraz w jakich formach gmina może realizować te zadania, jaki charakter mają te zadania? Teza artykułu brzmi, że zadania w ramach wieloletniego programu "Seniort" są zadaniami własnymi gminy z zakresu pomocy społecznej. Zadania te nie mają charakteru obligatoryjnego i są realizowane zarówno w sferze imperium, jak i dominium. Formy realizacji zadań przemawiają na rzecz tezy, że mamy do czynienia z prywatyzacją zadań z zakresu pomocy społecznej.

\section{Wieloletni program „Senior+" na lata 2015-2020}

Ze względu na wydłużającą się przeciętną długość życia, przy jednoczesnym spadku liczby urodzeń oraz wzrostem procesu starzenia się ludności, Rada Ministrów w dniu 17 marca 2015 r. podjęła uchwałę nr 34 w sprawie przyjęcia wieloletniego programu "Senior+". Program ten został stworzony w celu podjęcia działań bezpośrednio skierowanych do seniorów z zamiarem zwiększenia ich aktywnego uczestnictwa w życiu społecznym. Cel ten ma zostać zrealizowany m.in. poprzez rozbudowę infrastruktury ośrodków wsparcia w środowisku lokalnym oraz zwiększenie miejsc w placówkach "Senior+" przy dofinansowaniu działań jednostek samorządu w rozwoju na ich terenie sieci Dziennych Domów "Senior+" i Klubów "Senior+". Kolejnym celem jest zapewnienie wsparcia seniorom, tj. osobom nieaktywnym zawodowo w wieku 60+. Cel ten ma zostać zrealizowany przez umożliwienie korzystania przez seniorów z oferty na rzecz społecznej aktywizacji (oferty prozdrowotnej, obejmującej także usługi w zakresie aktywności ruchowej lub kinezyterapii, a także oferty edukacyjnej, kulturalnej, rekreacyjnej i opiekuńczej, w zależności od potrzeb stwierdzonych w środowisku lokalnym). Dla realizacji powyższego celu ma zostać udostępniona seniorom infrastruktura umożliwiająca aktywne spędzanie wolnego czasu, jak również zaktywizowanie i zaangażowanie seniorów w działania samopomocowe oraz działania na rzecz środowiska lokalnego. Program „Senior+" stanowi element polityki społecznej państwa w zakresie: „1) wsparcia finansowego jednostek samorządu w zakresie realizacji zadań własnych określonych w art. 17 ust. 2 pkt 3, art. 19 pkt 11 oraz art. 21 pkt 5 ustawy o pomocy społecznej, 2) poprawy jakości życia seniorów w środowisku lokalnym, 3) zapewnienia seniorom wsparcia oraz pomocy adekwatnej do potrzeb i możliwości wynikających z wieku i stanu zdrowia, w tym wsparcia specjalistycznego, 4) integracji społecznej środowiska seniorów, w tym rozwoju działań samopomocowych, 5) zwiększenia zaangażowania seniorów w życie społeczności lokalnych, 6) promowania aktywnego starzenia się" (Uchwała nr 34, 2015). Program "Senior+" na lata 2015-2020 ma zapewnić wsparcie finansowe dla realizacji zadań własnych gminy w zakresie prowadzenia i zapewnienia miejsc w domach pomocy społecznej i ośrodkach wsparcia o zasięgu gminnym oraz kierowanie do nich osób wymagających opieki (u.p.s., 2004, art. 17 ust. 2 pkt 3). Program ten został dedykowany dla wszystkich jednostek samorządu terytorialnego, a udział w nim ma charakter dobrowolny. 


\section{Zadania gminy w ramach programu „Senior+"}

W uchwale nr 34 określono także zadania organów na szczeblu administracji rządowej centralnej i w terenie, a ponadto w samorządach. Na gminę, która zdecyduje o udziale w programie "Senior+" zostały nałożone obowiązki: ogłoszenie o otwarciu placówki typu "Senior+" oraz zapewnienie możliwości skorzystania z ich usług przez ostatecznych beneficjentów, zapewnienie funkcjonowania placówek oraz utrzymania liczby miejsc, dowożenie seniorów, w szczególności mających trudności w poruszaniu się, określenie zasad funkcjonowania placówek oraz trybu kwalifikowania osób do uczestnictwa w działaniach realizowanych przez placówkę, w tym określenie kryteriów odpłatności za pobyt w placówce seniora, określenie kwalifikacji pracowników i współpracowników realizujących oferty usług w ramach Dziennego Domu "Seniort" oraz Klubu "Senior+".

W myśl Uchwały nr 34 do zadań wójta, burmistrza, prezydenta miasta należy m.in. złożenie oferty do właściwego wojewody wspólnej przez wszystkie jednostki. Ponadto przewidziano możliwość złożenia oferty w partnerstwie z podmiotami prowadzącymi działalność pożytku publicznego. Zadania organu wykonawczego obejmują również realizację następujących zadań: podpisanie umowy z wojewodą w zakresie tworzenia i prowadzenia Dziennych Domów "Seniort" oraz Klubów „Senior+", wykonanie zadań zgodnie z zawartymi umowami oraz rozliczenie z wojewodą otrzymanej dotacji. Zadanie to podlega kontroli, w tym celu wójt, burmistrz, prezydent miasta obowiązany jest przedstawić na żądanie wojewody wyjaśnień, informacji i dokumentów dotyczących zadania oraz przekazywać wojewodzie rocznych sprawozdań z realizacji Programu wraz z informacją o ciągłości funkcjonowania placówek "Senior+”.

Podsumowując należy przyjąć, że zadania te są zadaniami własnymi gminy w rozumieniu art. 18 ust. 2 pkt 3 u.p.s. z zakresu pomocy społecznej. Zadania te nie mają charakteru obligatoryjnego, co oznacza, że kwestię ich realizacji pozostawiono uznaniu gmin.

\section{Zakres podmiotowy i przedmiotowy programu „Senior+"}

W uchwale dotyczącej programu "Senior+" określono przesłanki podmiotowe i przedmiotowe oraz sposoby i formy realizacji tych zadań. Do podmiotów, które mogą realizować te zadania zaliczono wszystkie jednostki samorządu terytorialnego, a więc także i gminę. Ponadto podmiotami, które mogą ubiegać się o uzyskanie środków finansowych przeznaczonych na zapewnienie funkcjonowania już istniejących placówek są również Dzienne Domy „Senior-WIGOR", które zostały utworzone na podstawie zawartych umów dotacyjnych w latach 20152016 (Uchwała nr 34, 2015, pkt IV.1.9).

Z punktu widzenia osób uprawnionych do korzystania ze świadczeń w ramach programu "Senior+", należy wskazać, że dotyczy on przede wszystkim seniorów nieaktywnych zawodowo w wieku 60+. Muszą oni spełniać warunki określone w art. 97 ust. 1 i 5 u.p.s., które regulują kwestie odpłatności za świadczone usługi. Zarówno zasady funkcjonowania placówek, jak i tryb kwalifikowania osób do uczestnictwa w działaniach realizowanych przez placówkę uregulowane są w ustawie o pomocy społecznej. Pod uwagę będzie brane zatem kryterium dochodowe określone w art. 8 u.p.s. Nadto w odniesieniu do zajęć ruchowych (kinezyterapii), sportowo-rekreacyjnych i aktywizujących przewidziano wymóg stosownego zaświadczenia lekarskiego o braku przeciwwskazań do uczestnictwa w nich.

Zakres przedmiotowy programu "Senior+" obejmuje wsparcie dla tworzenia placówek typu "Senior+", w tym Dziennych Domów "Senior+" i Klubów "Senior+", przez te jednostki 
samorządu, których strategie rozwoju pomocy społecznej uwzględniają rozwój infrastruktury dla osób starszych, lub w których brak jest innej infrastruktury pomocy społecznej tego typu. Program "Seniort" nakierowany jest na ulepszenie już istniejących oraz tworzenie nowych placówek tego typu, przy czym dotacja nie może zostać przeznaczona na budowę nowego obiektu, czy zakup nieruchomości. Tworzenie placówki obejmuje przebudowę lub remont już istniejących obiektów albo ich części, i realizacji usług w zakresie dostosowanym do potrzeb seniorów. Gmina może wykorzystać także pomieszczenia, które zostały przebudowane lub wyremontowane w ramach inwestycji finansowanych z Programu Rozwoju Obszarów Wiejskich. W punkcie IV.2. Uchwały nr 34 określono minimalne standardy placówek oraz poziom zatrudnienia pracowników. Wprowadzono także zakaz tworzenia miejsca całodobowego pobytu w placówkach uruchamianych w ramach programu.

Działalność bieżąca Dziennego Domu "Seniort" polegać ma na realizacji podstawowych usług mających na celu udzielanie pomocy w czynnościach dnia codziennego, na zapewnieniu minimum jednego posiłku, w szczególności gorącego oraz innych usług wspomagających, dostosowanych do potrzeb seniorów. Natomiast działalność Klubu "Seniort" polegać ma na motywowaniu seniorów do działań na rzecz samopomocy i działań wolontariackich na rzecz innych.

Zdecydowano, że środki finansowe w ramach "Senior+" mogą zostać przeznaczone na:

1) Moduł 1 - jednorazowe wsparcie finansowe na utworzenie lub wyposażenie placówki w wysokości do $80 \%$ całkowitego kosztu realizacji zadania, które nie może być wyższe niż 300 tys. zł w przypadku Dziennego Domu "Senior+" oraz 150 tys. zł w przypadku Klubu "Senior+", z tym że wysokość środków finansowych z budżetu państwa przeznaczonych w ramach powyżej wskazanej kwoty na przebudowę lub remont pomieszczeń lub budynku, nie może być wyższa niż 250 tys. zł w przypadku Dziennego Domu "Senior+" oraz 125 tys. zł w przypadku Klubu "Senior+". Natomiast jednorazowa kwota dotacji przeznaczona na wyposażenie Dziennego Domu "Senior+" nie może być wyższa niż 80 tys. zł, a w przypadku Klubu "Seniort" - 25 tys. zł.

2) Moduł 2 - zapewnienie funkcjonowania już istniejących placówek. Dofinansowaniu $z$ budżetu państwa w każdym roku kalendarzowym, w trybie konkursowym mogą podlegać działania związane z bieżącym utrzymaniem placówki. Rocznie kwota dofinansowania na działalność bieżącą placówek uruchomionych w ramach programu na utrzymanie jednego miejsca wynosić będzie nie więcej niż 300 zł miesięcznie w Dziennym Domu "Senior+" oraz nie więcej niż 200 zł w Klubie "Senior+", przy czym dotacja nie może stanowić więcej niż 40\% całkowitego kosztu realizacji zadania (Uchwała nr 34, 2015, pkt IV.1.3.).

Zasadniczo utworzenie i wyposażenie placówki ma zostać sfinansowane z dotacji programu "Seniort" oraz środków własnych gminy. Z kolei funkcjonowanie placówki będzie finansowane w dwóch wyżej wymienionych źródeł oraz środków pochodzących z odpłatności ponoszonej przez uczestników.

\section{Sposoby i formy realizacji zadań przez gminę w ramach programu "Senior+"}

Przesądzenie o charakterze zadań w ramach programu "Senior+" stanowi podstawę do dalszych rozważań o sposobach oraz formach realizacji niniejszych zadań przez gminę.

Odnośnie sposobu realizacji zadań w ramach programu "Senior+" w uchwale nr 34 zdecydowano, że gmina może je realizować samodzielnie. Może także - po uzyskaniu dotacji na podstawie art. 25 ust. 1 i 5 u.p.s. - zlecać zrealizowanie ww. zadań organizacjom pozarządowym 
prowadzącym działalność pożytku publicznego, jak również osobom prawnym i jednostkom organizacyjnym działającym na podstawie przepisów o stosunku Państwa do Kościoła Katolickiego w Rzeczypospolitej Polskiej, o stosunku Państwa do innych kościołów i związków wyznaniowych oraz o gwarancjach wolności sumienia i wyznania, jeżeli ich cele statutowe obejmują prowadzenie działalności pożytku publicznego, stowarzyszeniom jednostek samorządu terytorialnego, spółdzielniom socjalnym, spółkom akcyjnym i spółkom z ograniczoną odpowiedzialnością oraz klubom sportowym będących spółkami działającymi na podstawie przepisów ustawy z dnia 25 czerwca 2010 r. o sporcie (Ustawa o sporcie..., 2010), które nie działają w celu osiągnięcia zysku oraz przeznaczają całość dochodu na realizację celów statutowych oraz nie przeznaczają zysku do podziału między swoich udziałowców, akcjonariuszy i pracowników. Ponadto gmina może również zrealizować te zadania w partnerstwie z wyżej wymienionymi podmiotami. Wyłonienie podmiotu realizującego zadania w ramach programu "Seniort" następuje w konkurencyjnych trybach. Przewidziano także możliwość realizacji tych zadań przez funkcjonujące już jednostki. Ośrodek wsparcia (Dzienny Dom/ Klub "Senior+") gmina może połączyć z ośrodkiem pomocy społecznej lub domem pomocy społecznej dla osób w podeszłym wieku lub dla osób przewlekle somatycznie chorych (u.p.s., 2004, art. 111a ust. 1).

Z punktu widzenia form organizacyjnoprawnych należy przyjąć, że zadania te mogą być realizowane samodzielnie przez gminy, które są uprawnione do prowadzenia domów pomocy społecznej, jak i innych placówek dziennych domów Senior+ czy klubów Senior+. Nadto istnieje możliwość na podobnych zasadach, jak określono to w ustawie o pomocy społecznej, zlecanie realizacji tych zadań organizacjom pożytku publicznego, bądź realizacji tych zadań w ramach partnerstwa z tymi organizacjami. Rozszerzenie katalogu podmiotów uprawnionych do realizacji zadań gminy stanowi przejaw prywatyzacji zadań publicznych (Biernat, 1994, s. 25-27; Nitecki, 2012, s. 106; Zacharko, 2000, s. 31). Pod pojęciem prywatyzacji zadań z zakresu administracji publicznej należy rozumieć zlecanie funkcji administracji na podstawie ustawy podmiotom, które nie wchodzą w skład aparatu administracyjnego, nie są organami administracji publicznej w znaczeniu ustrojowym (Stahl i in., 2016, s. 300). Podmiotami tymi mogą być przykładowo fundacje, stowarzyszenia, spółki prawa handlowego, organizacje pożytku publicznego, a nawet osoby fizyczne.

W uchwale nie określono w jakich prawnych formach działania gmina może te zadania realizować. W odniesieniu do zasad funkcjonowania placówek oraz trybu kwalifikowania osób do uczestnictwa w działaniach realizowanych przez placówkę (kryteriów odpłatności za pobyt w placówce seniora) w uchwale $\mathrm{nr} 34$ przyjęto, że właściwe organy będą ustalać powyższe kwestie w oparciu o przepis art. 97 ust. 1 i 5 u.p.s. Według art. 97 ust. 1 u.p.s. opłatę za pobyt w ośrodkach wsparcia i mieszkaniach chronionych ustala podmiot kierujący w uzgodnieniu z osobą kierowaną, uwzględniając przyznany zakres usług. Osoby nie ponoszą opłat, jeżeli dochód osoby samotnie gospodarującej lub dochód na osobę w rodzinie nie przekracza kwoty kryterium dochodowego. Stosownie do brzmienia art. 97 ust. 5 u.p.s., rada powiatu lub rada gminy w drodze uchwały ustala - w zakresie zadań własnych - szczegółowe zasady ponoszenia odpłatności za pobyt w ośrodkach wsparcia i mieszkaniach chronionych. Z powyższego wynika, że zadanie w zakresie określenia kryteriów odpłatności za pobyt w placówce seniora realizowane będzie $w$ formie aktu generalnego powszechnie obowiązującego - aktu prawa miejscowego (Wyrok NSA z 29.08.2008; Rozstrzygnięcie nadzorcze Wojewody Świętokrzyskiego, 2020; Rozstrzygnięcie nadzorcze Wojewody Kujawsko-Pomorskiego, 2020), który może być podejmowany wyłącznie na podstawie upoważnienia ustawowego oraz podlega publikacji w wojewódzkim dzienniku urzędowym. W praktyce orzeczniczej pojawiły się nastę- 
pujące problemy, które legły u podstaw stwierdzenia nieważności uchwał podejmowanych przez rady gminy. Gminy podejmowały uchwały, w których przewidywały jednocześnie utworzenie placówki oraz kryteria odpłatności za pobyt w placówce seniora. W istocie w uchwałach łączono treści normatywne aktów o charakterze wewnętrznym i aktów prawa miejscowego. Należy zauważyć, że utworzenie jednostki organizacyjnej następuje w drodze indywidualnego aktu organizacyjnego niepodlegającego publikacji w dzienniku promulgacyjnym (Wyrok NSA z 07.12.2005; Wyrok NSA z 19.02.2010). Jest to bowiem akt o charakterze wewnętrznym. Natomiast zasady odpłatności za pobyt w placówce seniora uchwalane są przez radę gminy w drodze uchwały, która jest aktem prawa miejscowego i podlega publikacji we właściwym dzienniku promulgacyjnym, tj. wojewódzkim dzienniku urzędowym (zob. Rozstrzygnięcie nadzorcze Wojewody Kujawsko-Pomorskiego, 2020). Rady gmin podejmowały także uchwały regulujące zwolnienie generalne lub częściowe uczestników Klubu z obowiązku ponoszenia opłat, wskazujące na konkretny wymiar ponoszonej opłaty (stawki (wskaźniki) opłat wyrażone procentowo i uzależnione od wysokości dochodu), regulowanie kwestii nadzoru i kontroli w zakresie realizacji ww. zadań, co stanowiło w ocenie organu nadzoru przekroczenie zakresu upoważnienia zawartego w art. 97 ust. 5 u.p.s. (zob. Rozstrzygnięcie nadzorcze Wojewody Świętokrzyskiego, 2020; Rozstrzygnięcie nadzorcze Wojewody Kujawsko-Pomorskiego, 2019a i 2019 b; Rozstrzygnięcie nadzorcze Wojewody Wielkopolskiego, 2019). Za nieprawidłowe uznano także uchwały podjęte na podstawie art. 97 ust. 5 u.p.s. regulujące długość pobytu w placówce, formy przyznania świadczenia i osoby upoważnionej do przyznania świadczenia, elementów uwzględnianych przy wydaniu decyzji w sprawie o odpłatności, postępowania po ustaniu prawa do świadczenia (zob. Wyrok WSA we Wrocławiu z 28.08.2014). Uznano, że przepis art. 97 ust. 1 odnosi się do wydania decyzji w sprawach indywidualnych i nie może stanowić podstawy do podjęcia uchwał określających zasady odpłatności za pobyt w Dziennym Domu "Senior+" lub Klubie "Senior+".

W odniesieniu do zadań wójta określonych w uchwale nr 34 należy wskazać, że będą to zarówno zadania o charakterze władczym, jak i niewładczym. Wójt (burmistrz, prezydent miasta) jest organem właściwym do wydawania decyzji w indywidualnych sprawach w zakresie kierowania osób uprawnionych do korzystania ze świadczeń w ramach program "Senior+". W orzecznictwie na tle interpretacji przepisów art. 110 ust. 7 u.p.s. regulującego obligatoryjne upoważnienie oraz art. 39 ust. 1 u.s.g. powstał spór - czy wójt (burmistrz, prezydent) jest organem właściwym w sprawach z zakresu pomocy społecznej. Zgodnie z art. 110 ust. 7 u.s.p. wójt, burmistrz lub prezydent miasta udziela kierownikowi ośrodka pomocy społecznej upoważnienia do wydawania decyzji administracyjnych w indywidualnych sprawach z zakresu pomocy społecznej należących do właściwości gminy. W myśl art. 39 ust. 1 ustawy z dnia 8 marca 1990 r. o samorządzie gminnym (Ustawa o samorządzie gminnym..., 1990) decyzje w sprawach indywidualnych z zakresu administracji publicznej wydaje wójt, o ile przepisy szczególne nie stanowią inaczej.

Według jednej linii orzeczniczej w świetle art. 110 ust. 7 u.p.s. - stanowiącej przykład dekoncentracji kompetencji - wójt nie jest organem właściwym do prowadzenia postępowania w sprawach z zakresu pomocy społecznej (zob. Wyrok NSA z 21.12.2007). Z kolei według drugiej linii orzeczniczej, fakt „przeniesienia kompetencji orzeczniczych na kierownika ośrodka nie powoduje zmiany właściwości organu, a wydana w sprawie decyzja jest w dalszym ciągu decyzją wójta" (por. Wyrok NSA z 12.03.2013; Wyrok NSA z 27.10.2015; Wyrok NSA z 18.06.013; Wyrok WSA w Szczecinie 04.04.2019). 
Autorka podziela pogląd, zgodnie z którym upoważnienie kierownika ośrodka pomocy społecznej do wydawania decyzji w indywidualnych sprawach z zakresu pomocy społecznej nie stanowi przeniesienia kompetencji wójta (burmistrza, prezydenta miasta) do rozstrzygania spraw z zakresu pomocy społecznej na kierownika ośrodka pomocy społecznej. Nadal piastun funkcji organu zachowuje swoje kompetencje, natomiast kierownik ośrodka pomocy społecznej wydaje decyzje z upoważnienia organu wykonawczego gminy i w zakresie jego kompetencji. Powyższe nie oznacza, że kierownik ośrodka pomocy społecznej na podstawie takiego upoważnienia staje się organem załatwiającym określony rodzaj spraw. Natomiast w odniesieniu do zawarcia umowy oraz jej wykonania, dowozu seniorów do placówek, udostępnianiu infrastruktury, mamy do czynienia z czynnościami cywilnoprawnymi oraz czynnościami materialnotechnicznymi, a zatem formami o charterze niewładczym.

\section{Podsumowanie}

Prowadzone rozważania w oparciu o regulacje prawne oraz stanowisko judykatury prowadzą do następujących konkluzji. Zadania gminy w ramach programu "Senior+" mają charakter zadań własnych gminy z zakresu pomocy społecznej, przy czym są to zadania nieobowiązkowe. W ramach programu "Senior+" przewidziano kompetencje zarówno dla organu stanowiącego, jak i organu wykonawczego gminy. Organ stanowiący na szczeblu gminy może te zadania realizować zasadniczo w formie aktów prawa miejscowego, np. w zakresie ustalenia kryteriów odpłatności za pobyt seniora w placówkach. Nadto zadania te może realizować w formie indywidualnych aktów organizacyjnych, jeżeli dana gmina zamierza utworzyć taką jednostkę. Z kolei organ wykonawczy gminy realizuje ww. zadania zarówno w formach władczych w postaci kwalifikowanego aktu prawnego - decyzji administracyjnej oraz w drodze czynności cywilnoprawnych i materialnotechnicznych. Zadania te mogą realizować już funkcjonujące jednostki - Dzienne Domy "Senior-WIGOR”.

Z punktu widzenia podmiotów realizujących powyższe zadania wskazać należy, że zakres podmiotów, które mogą realizować zadania w ramach programu "Senior+" został zdecydowanie określony szeroko. Powyższe umożliwia gminom realizację tych zadań samodzielnie na zasadach ogólnych, jak i zaangażowanie podmiotów usytuowanych poza aparatem administracyjnym - głównie organizacji pożytku publicznego. Zlecanie zadań z zakresu administracji publicznej podmiotom usytuowanym poza aparatem administracyjnym stanowi przejaw prywatyzacji zadań administracyjnych. Mamy tu bowiem do czynienia z odstępstwem od klasycznej realizacji zadań publicznych wyłącznie przez organy administracji publicznej i wyłącznie w formach publicznoprawnych o charakterze władczym na rzecz podmiotów usytuowanych poza strukturami administracji publicznej, które dobrowolnie mogą przystępować do ich realizacji. Zaangażowanie podmiotów pożytku publicznego sprzyja „integracji zawodowej i społecznej osób zagrożonych marginalizacją społeczną, tworzeniu miejsc pracy, świadczeniu usług społecznych użyteczności publicznej (na rzecz interesu ogólnego) oraz rozwojowi lokalnemu" (Małecka-Łyszczek, 2018, s. 19). Powyższe rozwiązanie należy ocenić jako pozytywne z punktu widzenia odciążenia funkcjonowania administracji publicznej oraz funkcji integracyjnej ukierunkowanej na eliminację wykluczenia społecznego seniorów.

Należy, jednakże poczynić pewne uwagi. Pomimo zaangażowania podmiotów usytuowanych poza strukturami administracji, organy gminy nadal pozostają właściwe w sprawach im poruczonych. Powyższe nie oznacza, że można delegować kompetencje do wydawania decyzji administracyjnych przez wójta (burmistrza, prezydenta miasta) na rzecz organizacji pożytku 
publicznego. Z całą pewnością wójt (burmistrz, prezydent miasta) może upoważnić kierowników ośrodków pomocy społecznej do wydawania takich decyzji, i powyższe nie oznacza wyłączenia kompetencji organu wykonawczego gminy. Z kolei rada gminy nie może cedować swoich kompetencji na rzecz organu wykonawczego gminy, czy też jednostki organizacyjnej i upoważnić do uregulowania kwestii odpłatności za pobyt seniora w tych placówkach.

Inicjatywę w zakresie aktywizacji osób starszych należy ocenić pozytywnie. W ten sposób realizowana jest funkcja opiekuńcza państwa. Usytuowanie tych zadań na poziomie gminy należy uznać za trafne z wielu powodów. Dzięki programowi "Senior+” gminy mogą uzyskać dodatkowe środki finansowe na realizację polityki senioralnej, w szczególności na stworzenie warunków do zwiększenia aktywnego i zdrowego trybu życia seniorów, udzielanie pomocy w czynnościach dnia codziennego, zapewnienie minimum jednego posiłku, w szczególności gorącego, czy też innych usług wspomagających dostosowanych do potrzeb seniorów. Działania podejmowane w ramach programu sprzyjają integracji społeczności lokalnej, podnoszenie kompetencji i umiejętności seniorów. Ponadto z całą pewnością program ten jest jednym z przedsięwzięć wspierających działania ukierunkowane na przeciwdziałanie wykluczeniu starzejącego się społeczeństwa. Program stwarza także możliwość zagospodarowania istniejącej infrastruktury pozostającej w zasobach danej gminy, np. wykorzystania istniejących budynków zlikwidowanych szkół, w szczególności w gminach wiejskich, czy też innych obiektów użyteczności publicznej.

\section{Literatura}

Andruszkiewicz, A. (2017). Rady seniorów jako przykład ciał kolegialnych reprezentujących środowiska osób starszych w ramach realizacji zadań własnych gmin - analiza formalna ich funkcjonowania na przykładzie aktów prawa miejscowego wybranych miast Polski. W: B. Dolnicki (red.). Sposoby realizacji zadań publicznych (s. 21-31). Warszawa: Wolters Kluwer.

Augustyniak, M., Barczewska-Dziobek, A., Czerw, J., Maroń, G., Wójtowicz-Dawid, A. (2016). Gminne rady seniorów - wykładnia przepisów i efekty ich stosowania. Wzory i schematy działań. Warszawa: Wolters Kluwer, Lex/ el.

Behr, J. (2018). Przykłady ochrony prawnej przed wykluczeniem społecznym w prawie międzynarodowym. W: J. Behr, J. Blicharz (red.). Ochrona prawna przed wykluczeniem społecznym (s. 119-131). Wrocław: E-Wydawnictwo. Prawnicza i Ekonomiczna Biblioteka Cyfrowa. Wydział Prawa, Administracji i Ekonomii Uniwersytetu Wrocławskiego.

Biernat, S. (1994). Prywatyzacja zadań publicznych. Problematyka prawna. Warszawa: Wydawnictwo Naukowe. PWN.

Blicharz, J. (2018). W poszukiwaniu źródeł ochrony prawnej przed zjawiskiem wykluczenia społecznego w polskim prawie. W: J. Behr, J. Blicharz (red.). Ochrona prawna przed wykluczeniem społecznym (s. 35-77). Wrocław: E-Wydawnictwo. Prawnicza i Ekonomiczna Biblioteka Cyfrowa, Wydział Prawa, Administracji i Ekonomii Uniwersytetu Wrocławskiego.

Chmielnicki, P. (2013). Ustawa o samorzązie gminnym. Komentarz. Warszawa: Lexis Nexis, Lex/el.

Malarewicz-Jakubów, A. (2017). Wsparcie prawne osób starszych. Warszawa: WKP, Lex/el.

Małecka-Łyszczek, M. (2018). Ekonomia potencjału i oczekiwań - wybrane uwagi na tle Krajowego Programu Rozwoju Ekonomii Społecznej. Ekonomia Społeczna, 2, 16-22. https://doi.org/10.15678/ES.2018.2.02.

Mędrzycki, R. (2017), Funkcje gminnych rad seniorów. Ruch Prawniczy, Ekonomiczny i Społeczny, 3, 119-131. https://doi.org/10.14746/rpeis.2017.79.3.10.

Mikołajczyk, B. (2012). Międzynarodowa ochrona praw osób starszych. Warszawa: WKP, Lex/el

Minkowski, A. (2013). Rola samorządu terytorialnego w kształtowaniu aktywności osób starszych dzięki zastosowaniu technologii teleinformatycznych i e-usług. International Business and Global Economy, 32, 147-157. DOI: $10.4467 / 23539496 \mid B .13 .010 .2646$.

Moll, T. (2015). Rada seniorów - sposób realizacji potrzeby zwiększania aktywności społecznej osób starszych. Samorzą Terytorialny, 11, 66-76. 
Nitecki, S. (2012), Udział podmiotów niepublicznych w realizacji zadań pomocy społecznej, Roczniki Administracji i Prawa Teoria i Praktyka, 12, 105-118.

Piechowiak, M. (2009). Konstytucja wobec wykluczenia społecznego. W: Z. Kędzia, A. Rost (red.). Współczesne wyzwania wobec praw człowieka w świetle polskiego prawa konstytucyjnego (s. 125-145). Poznań: Wydawnictwo Naukowe UAM.

Rosztrzygnięcie nadzorcze Wojewody Wielkopolskiego z dnia 20 grudnia 2019, KN-I.4131.1.517.2019.22, Dz.Urz. Woj.Wlkp. 2019 nr 244, poz. 11130.

Rozstrzygnięcie nadzorcze Wojewody Kujawsko-Pomorskiego z dnia 19 kwietnia 2019a, 40/2019, Dz.Urz.Woj. Kuj.-Pom. 2019 nr 67, poz. 2455.

Rozstrzygnięcie nadzorcze Wojewody Kujawsko-Pomorskiego z dnia 2 lipca 2019b. 55/2019, Dz.Urz.Woj.Kuj.-Pom. 2019 nr 108, poz. 3816.

Rozstrzygnięcie nadzorcze Wojewody Kujawsko-Pomorskiego z dnia 20 stycznia 2020, 9/2020, Dz.Urz.Woj.Kuj.-Pom. 2020 nr 13, poz. 465.

Rozstrzygnięcie nadzorcze Wojewody Świętokrzyskiego z dnia 3 lutego 2020, PNK.I.4130.13.2020, Dz.Urz.Woj. Święt. 2020 nr 26, poz. 686.

Stahl, M., Duniewska, Z., Jaworska-Dębska B., Kasiński, M. Olejniczak-Szałowska E. (2016). Prawo administracyjne. Pojęcia, instytucje, zasady w teorii i orzecznictwie. Warszawa: Wolters Kluwer business, Warszawa.

Tuleja, P. (2009). Prawa jednostki do ochrony przed wykluczeniem a konstytucyjne zadania państwa. W: Z. Kędzia, A. Rost (red.). Współczesne wyzwania wobec praw człowieka w świetle polskiego prawa konstytucyjnego (s. 147-163), Poznań: Wydawnictwo Naukowe UAM.

Uchwała nr 34 Rady Ministrów w dniu 17 marca 2015 w sprawie ustanowienia programu wieloletniego "Seniort" na lata 2015-2020, tekst jedn. M.P. z 2018 r. poz. 228.

Ustawa z dnia 12 marca 2004 r. o pomocy społecznej, tekst jedn. Dz.U. z 2019 r. poz. 1507, ze zm.

Ustawa z dnia 25 czerwca 2010 r. o sporcie, tekst jedn. Dz.U. z 2019 r. poz. 1468, ze zm.

Ustawa z dnia 8 marca 1990 r. o samorządzie gminnym, tekst jedn. Dz. U. z 2019 r. poz. 506, ze zm.

Wyrok NSA z 07.12.2005, II OSK 332/05, Legalis nr 75593.

Wyrok NSA z 12.03.2013, I OSK 1158/12, LEX nr 1356929.

Wyrok NSA z 18.06.013, I OSK 377/13, LEX nr 1557329.

Wyrok NSA z 19.02.2010, I OSK 1628/09, Legalis nr 223640.

Wyrok NSA z 21.12.2007, I OSK 383/07, LEX nr 372671.

Wyrok NSA z 27.10.2015, I OSK 1420/15, LEX nr 2002573.

Wyrok NSA z 29.08.2008, I OSK 1430/07, LEX nr 477405.

Wyrok WSA w Szczecinie 04.04.2019, II SA/Sz 64/19, LEX nr 2646003.

Wyrok WSA we Wrocławiu z 28.08.2014, IV SA/Wr 629/13, Legalis nr 759454.

Zacharko, L. (2000), Prywatyzacja zadań gminy. Studium administracyjnoprawne. Katowice: Wydawnictwo Uniwersytetu Śląskiego.

\section{Activation of the elderly at the commune level}

Summary: The multiannual "Senior +" program for 2015-2020 adopted by resolution No. 34 by The Council of Ministers on March 17, 2015 is a planning act that addresses the issue of activation of senior citizens. The subject of the study is primarily the presentation of the current legal status and jurisprudence on the implementation of tasks specified in this act. Considerations are conducted from the point of view of forms and ways of implementing tasks by the commune in the area of activating elderly people under the "Senior +" program and assessing the nature of these tasks. The article employs the theoretical and dogmatic method.

Keywords: activation of the elderly, senior +, commune tasks

JEL codes: $J 14 ; J 18$

\section{Informacje 0 autorze}

\section{Dorota Sylwestrzak}

ORCID 0000-0003-4985-2880

Katedra Prawa Administracyjnego

Uniwersytet Mikołaja Kopernika w Toruniu 
ul. Wł. Bojarskiego 3

87 - 100 Toruń

e-mail: d_syl@law.uni.torun.pl

\section{Prawa autorskie i licencja / Copyright and License}

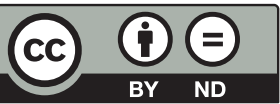

BY ND
Publikacja na licencji Creative Commons Uznanie autorstwa Użycie niekomercyjne - Bez utworów zależnych 4.0 Międzynarodowe (CC BY-ND 4.0) http://creativecommons.org/licenses/by-nc-nd/4.0/deed/pl

This work is published under the terms of the Creative Commons Attribution - NoDerivetives International (CC BY-ND 4.0) License http://creativecommons.org/licenses/by-nc-nd/4.0

Wydane przez Uniwersytet Ekonomiczny w Krakowie. Małopolska Szkoła Administracji Publicznej

Published by Cracow University of Economics - Krakow, Poland. Małopolska School of Public Administration of the Cracow University of Economics 